\section{Intersections}

Canadian Journal of Music

Revue canadienne de musique
Intersections CANADIAN JOURAL OF MUSIC

\title{
Leçons de Tenebrae: Brian Cherney, Paul Celan, and a Music of Witness
}

\section{Anton Vishio}

Volume 37, numéro 1, 2017

Illuminations: Essays in Honour of Brian Cherney

URI : https://id.erudit.org/iderudit/1059893ar

DOI : https://doi.org/10.7202/1059893ar

Aller au sommaire du numéro

\section{Éditeur(s)}

Canadian University Music Society / Société de musique des universités canadiennes

ISSN

1911-0146 (imprimé)

1918-512X (numérique)

Découvrir la revue

Citer cet article

Vishio, A. (2017). Leçons de Tenebrae: Brian Cherney, Paul Celan, and a Music of Witness. Intersections, 37(1), 157-179. https://doi.org/10.7202/1059893ar
Résumé de l'article

Plusieurs compositions de Brian Cherney sont une réflexion sur l'Holocauste et son impact; elles explorent la manière dont la musique peut répondre à une telle tragédie. Son rapprochement récent de la poésie de Paul Celan constitue un prolongement naturel de ces préoccupations. Dans cet essai, l'auteur propose une lecture intime de l'interprétation chorale par Cherney du Tenebrae de Celan. Le compositeur intègre plusieurs textes additionnels qui créent une généalogie du poème, notamment des passages bibliques, des fragments de Dante et Höderlin, et des comptes rendus de l'Holocauste comme tel ; il structure ces textes pour mettre en valeur les aspects sémantiques et soniques de l'oeuvre de Celan. La décision sans doute la plus audacieuse de Cherney a été d'inclure des lettres hébraïques, faisant ainsi le lien entre sa composition et la longue tradition du cadre des Lamentations ; ce lien est renforcé par une citation des Leçons de Ténèbres de Couperin, créant un matériel motivique important. Par ces ajouts, Cherney nous renvoie le poème et nous invite à répondre à son appel à être des témoins réfléchis.
Copyright @ C Canadian University Music Society / Société de musique des universités canadiennes, 2019
Ce document est protégé par la loi sur le droit d'auteur. L’utilisation des services d'Érudit (y compris la reproduction) est assujettie à sa politique d'utilisation que vous pouvez consulter en ligne.

https://apropos.erudit.org/fr/usagers/politique-dutilisation/ 


\title{
LEÇONS DE TENEBRAE: BRIAN CHERNEY, PAUL CELAN, AND A MUSIC OF WITNESS ${ }^{1}$
}

\author{
Anton Vishio
}

As an epigraph for his choral setting of Paul Celan's poem "Tenebrae" Brian Cherney provides a poignant quotation from the poet: "Kämen Menschen, ich könnte fast neu beginnen" (If only people would come, I could almost begin anew). ${ }^{2}$ This line, however, is not to be found in any published poem; in fact, it was almost destined never to see the light of day. Its discoverer, John Felstiner, Celan's leading English-language biographer and interpreter, came upon it in the back of a "frayed, hand-worn" volume of Kafka's short stories that had accompanied Celan through a lengthy psychiatric confinement in December 1965. Felstiner grippingly describes finding this and other "terrifying pained scrawlings" nearly twenty years later, very early one morning while going through Celan's personal library in his Paris apartment (Celan 2001, xxiv-xv). He had been accorded browsing privileges, yet this particular volume clearly retained a raw emotional dimension beyond others; Celan's widow, Gisèle Celan-Lestrange, entered the room just then and asked him to place the book back on the shelves. It took a full decade for Felstiner to feel comfortable asking permission to reveal the discovery in print; even then, he remained haunted by the experience, taking several more years to reveal its full force (Felstiner 2010, 202).

One can readily imagine the unbearable potency of this moment. Celan's scrawled plea, less than five years before his suicide, was a desperate reachingout - all the more desperate in its being a plea destined to fail, in its disguise as a random jotting on endpapers tucked away in a personal library. Yet its companion notations reveal something of what other people-what we as wellwere and are being summoned for: something of that new strength from which Celan might-just might-have been able to proceed. One of those notations, as transcribed by Felstiner, was "Hear, O Israel, the Lord our God, the Lord is One"; Felstiner describes this as the "essential profession of faith [of] Jewish

1 I am grateful to Robin Elliott and three anonymous reviewers for their comments.

2 Cherney's setting was commissioned by the Montreal-based choir Viva Voce, with the aid of a grant from the Canada Council; it was completed in 2002.

3 As I worked on an early version of this project, I was saddened to learn of Felstiner's passing, in February 2017; in honour of the impact his writings on and translations of Celan have had on me, Brian Cherney, and many others, I dedicate this article to his memory. 
martyrs" across the millennia. Through it, we are being called not merely to come to the poet's aid, but also to hear, and to witness through this hearing: to witness his suffering, and through him the suffering of those whose voices Celan endeavoured so hard to keep from vanishing. We are being called to ease his burden, to share in an act of sustenance. 4

It is no surprise that such a call to witness would speak so powerfully to Brian Cherney; Matthew Ricketts has carefully detailed the development of the composer's musical practice of witnessing in a number of compositions, notably in connection to a photograph of a woman destined to perish in Auschwitz that the composer came across while composing the viola solo Shekhinah, and the traces of that solo in the orchestral work Transfiguration (Ricketts 2017, 108-32). It remains challenging to devise ways of bringing such witnessing to musical life, of expressing musical connections to the Other; but as Felstiner remarked of Celan, "The difficulty of bearing witness engenders the need" (Felstiner 1995, 35), a creative urge that seems to be shared by Cherney as well. Thus it seems particularly significant that Cherney has turned to a direct engagement with Celan's poetry over the past twenty years, resulting in three settings for soprano and piano; another choral work, Die Niemandrose, his 2006 setting of two poems from the volume of that title; and a more recent composition for chamber ensemble, Entretiens avec Paul Celan (2012). ${ }^{5}$ I shall focus here on his setting of Tenebrae for its intrinsic musical value, for its own reimagining of the tradition of composing Lamentations in Western musical history, and for its position within the astonishingly large number of settings of Celan's poetry in general and of this work in particular. ${ }^{6}$

Otto Pöggeler and Jean Bollack, key interpreters of the poet, are the sources for our information that in writing "Tenebrae" Celan was inspired at least in part by a musical source: the Leçons de Ténèbres of Francois Couperin, a recording of which he evidently owned (Pöggeler 1986, 405; 1993, 73; Janz 1976, 225). Indeed this title-of course not only Couperin's-was initially adopted by Celan, before he settled on the more "priestly" nature of the Latin Tenebrae (Felstiner 1995, 101). But the nature of any further connection-even whether Celan actually heard a performance of Couperin's work-is unclear; an extensive recent survey of Celan's musical affinities, culled from letters and recollections, reveals his interest in Bartók, his felt kinship with Schoenberg and Webern, his enthusiasm for Hugo Wolf's setting of Eduard Mörike's Gesang

4 The result of such sharing can be transformative; one more hopeful appeal occurs at the end of "Es war Erde in ihnen," one of the poems of Celan set by Cherney in Die Niemandrose: "O you dig and I dig and I dig through to you, and the ring on our finger awakens" (Celan 2001, 135).

5 To this list should be added the theatre piece Brahms and the German Spirit (2009), with its meditation on the damage wrought to European high musical culture by the Holocaust and its eradication of Eastern European culture (Cherney, personal communication); the work is prefaced with a quotation from Celan's poem "Schwarze Flocken." In addition, his Tombeau for piano (1997) features a quotation from his setting of "Vom Blau," a poem from Celan's first collection, Mohn und Gedächtnis.

6 A recent catalogue lists twenty settings of "Tenebrae" between 1959 and 2009; only "Todesfugue" has been set more often among Celan's poems (Bonnet and Marteau 2015, 532). Cherney's setting is not included. 
Weylas, and perhaps most notably his sympathy for the relatively obscure German Baroque composer Johann Rosenmüller, whose life was marked as Celan's was by the experience of exile (Marteau 2015, 41-58).7 But further documentation of a link to Couperin is elusive.

Whatever Celan's experience of it, the influence of Couperin's setting on his poem is not easy to characterize. For instance, Axel Englund has claimed that Celan's poem was written with the Couperin "in mind" (Englund 2012, 92). But even given the circumstances of the poem's creation as reported by the poet to Pöggeler the following month-that it had come to the poet while walking in the street, then transcribed when he arrived home-this is implausible on musical grounds; ${ }^{8}$ Couperin's work is the gorgeously florid articulation of a personal devotion, while Celan's is the terse expression of the calamity of millions:

Near are we, Lord

Pray, Lord,

pray to $u s$,

we are near. ${ }^{9}$

Pöggeler initially convinced Celan to drop what he termed this "sacrilegious" "pray to us," but the poet soon restored the verse. Such "sacrilege" already pervades the poem: we come first, before the Lord, whom we find wanting. Ultimately Felstiner's description of the relationship of Couperin and Celan as one of provocation seems most apt. As Jean Marcel Vincent emphasizes, the preoccupations expressed in "Tenebrae" ran deep in Celan's poetic practice; indeed, the resonances of the Lamentations text would have been ample stimuli in their own right: "The vertiginous depths of darkness [ténèbres] moreover unfolds in the biblical texts themselves" (Vincent 2007, 219). ${ }^{10}$ An encounter with the Couperin may have sparked this poem, but its groundwork was long laid.

There remains the influence of the formal shape of the musical setting of Lamentations and its impacts, both positive and negative, on Celan's practice. One of the great and frequently remarked pleasures of so many settings

7 Rosenmüller composed a fine setting of the Lamentations sometime in the second half of the seventeenth century; by providential coincidence, the German tenor Fritz Wunderlich recorded excerpts from it in late March 1957, just a couple weeks after the composition of "Tenebrae." I do not know if Celan ever heard it.

8 The theologians Paul M. Joyce and Diana Lipton acknowledge the Couperin as "among the most beautiful settings," but find "jarring disjunctions" between the music and the text that it sets, something they find in other settings of the time: "The music ... hovers harmoniously above the language of the text, failing to distinguish ... the triumphal from the tragic" (Joyce and Lipton 2013, 4750). It seems reasonable to imagine that Celan would have felt similar qualms. Pöggeler has even suggested that Celan's poetic audacity is better matched by the "audacious chromaticism" of Gesualdo's settings (Pöggeler 1993, 73). Celan did consider the possibility of a solo setting of the work, asking the composer Aribert Reimann to consider setting it for voice and piano the year after its composition (Englund 2012, 91); so it is not Couperin's solo voice that might have disturbed, but rather its style.

9 Emphasis added. This translation, as well as others from “Tenebrae” in the text, is Felstiner's, from Celan $(2001,103)$.

10 "Cette profondeur vertigineuse des ténèbres se déploie d'ailleurs dans les textes bibliques eux-mêmes.” 
of Lamentations in the (mainly) Catholic tradition are their treatments of the Hebrew letters that precede the verses, equivalents of the ornately designed initials in medieval manuscripts. But it is far too easy to miss the sense of erasure that is involved in such ornament, at least when the original text is compared with its later versions. After all, in the original Lamentations the twenty-two letters of the Hebrew alphabet fundamentally order the text as an acrostic. Explaining the appearance of the acrostic technique in "some of the most exalted Hebrew poetry," Hans T. David notes that "the alphabet also contained all conceivable meaningful sounds ... by using each letter in alphabetic sequence and in such a manner that equal importance was given to it, the unity of the alphabet was thus carried over into poetry" (David 1972, 7). This most "rational of forms" then constitutes a ritual, but of a particularly organic kind, built out of the order of the language itself. But the presence of the letters in works that reinterpret and modify the text in the light of Christian ritual destroys this organicism. The Hebrew letters in this reading have simply ceased to mean-ceased to have the ability to form words, and hence to insist on the non-Christian referents of the texts they organize. As David remarks, "Tradition kept them in their places ... but the reason for their introduction was no longer intelligible" $(1972,9)$. They become marks of otherness, whose expanded musical setting was rather a symptom of their loss: music rushing in where language could no longer tread.

Surely the reduction of Hebrew to a mere index, standing apart from the text rather than inside it, would have been anathema to Celan. But in "Tenebrae" he reassigns their formal function in a way that is perhaps no less disturbing. What replaces the letters that have ceased to mean is a Lord who has ceased to function, who has abandoned his people: Herr is the new index, and for precisely half of the twenty-two lines of the poem, a number that of course corresponds to the number of letters of the Hebrew alphabet and hence the number of verses in most of the Lamentations chapters, Herr is the end word. ${ }^{11}$ Such placement indicates how far we are from the more familiar terrain of invocation such as one finds at the beginning of Bach's St. John Passion and its summoning of "Herr, Herr, Herr, unser Herrscher."

Having considered why Celan might have omitted Hebrew letters from his "Tenebrae," we now must turn to how a musical setting of the poem might lead to their reinscription-for Cherney reintroduces them! His program note makes this decision seem entirely innocuous: "I have kept the convention, used in many settings of the Lamentations of Jeremiah, of preceding each stanza by a letter of the Hebrew alphabet." Yet their formal function here is much more fluid than any such convention might imply. For one thing, there are nine "stanzas," but only eight Hebrew letters are used; the final couplet is left unindexed. For another, the Hebrew letters join Herr and an additional, nonvocal sound, glockenspiel plates suspended from music stands, to form three

11 Since their use is particular important to analytical arguments to come, I will adopt a convention of capitalizing and italicizing both Herr and Hebrew letters in what follows. 
possible indexing schemes operative in the work. ${ }^{12}$ At various points in the setting, any and all of these can have-or not-a role in articulating formal boundaries.

This treatment of the letters, as one structural marker among many, already signals a departure from their use in the traditional musical approaches to Lamentations. An even more remarkable departure emerges from considering the details of their musical treatment: Cherney does not set the letters as alien figures in the verbal landscape, but rather on an equal footing with the other materials. What is sacrificed in the loss of the decorative capital is more than redeemed by the newfound pleasures of the resulting musical continuities. Consider just the first and last settings. Figure 1 shows how Aleph takes part in a gradual opening, a kind of seamless continuum from the initial glockenspiel attack through the entry of the full chorus with the beginning of Celan's poem in bar 3. A brief but compelling harmonic argument unfolds; the $\mathrm{C} \sharp-\mathrm{D}$ clash between the ringing plate and the tenor note of the Aleph is expressed both as the difference between two inversionally related [025] trichords, $\{B, D, E\}$ and $\{B, C \sharp, E\}$, and the intersection between two inversionally related [0237] tetrachords, $\{B, C \#, D, F \sharp\}$ and $\{A, C \#, D, E\}$.

In figure 2, Het by contrast seems to follow and subtly realign the preceding material. Cherney sets "It shines" as a complex of neighbour notes around a B-major triad, a common-tone augmented sixth save for the loss of the common tone itself, as if the shimmering chord temporarily obscures it. Het then echoes the third and fifth of the embellished triad, but omits the root, subtly weighting $\mathrm{D} \sharp$ as a more significant note-which now is supported by the glockenspiel dropping a half step to $A \sharp$ (notated $B$ b), suggesting the inexorable movement of a neo-Riemannian leading tone exchange. This unsettled harmonic movement then forms the basis for the return to Celan's text, and the uncertain image of the Lord "cast ... into our eyes."

Other additions to the Celan quickly command our attention. Cherney has surrounded the poem not just with the "reincarnated" Hebrew letters, but also with an extensive genealogy of related texts; he writes, in a prefatory note to the score, "In my setting of [Tenebrae] I have added text fragments drawn from other sources to form a kind of counterpoint or gloss to the poem itself, in order to comment, underline, extend, etc." In a discussion of settings of "Tenebrae" by Harrison Birtwistle and Luciano Berio, David Osmond-Smith explored the question of what happens when a text so laden with meaning is set to music; he counsels that "the music does not create an exegesis as a critic or philosopher would"; rather, "it extracts certain words, certain images, and begins to develop their formal potentials" (Osmond-Smith 2005, 65). ${ }^{13}$ But by

12 Cherney indicates that "suspended crotales or small handbells" could replace the plates, or a percussionist could perform the notes on glockenspiel or vibraphone-or even a "measure of silence" could replace these if unavailable. I am grateful to Peter Schubert for his assistance in obtaining this information.

13 "La musica non crea un'esegesi, come farebbe un critico o un filosofo ... Estrae certe parole, certe immagini, e si mette a svilupparne le potenzialità formali." Indeed, it is not clear to me that Birtwistle and Berio are not performing some kind of exegetical acts in their accompanying choices of poetry by Celan (in Pulse Shadows) or by others (in Stanze). For instance, Dimitri Kerdiles describes 


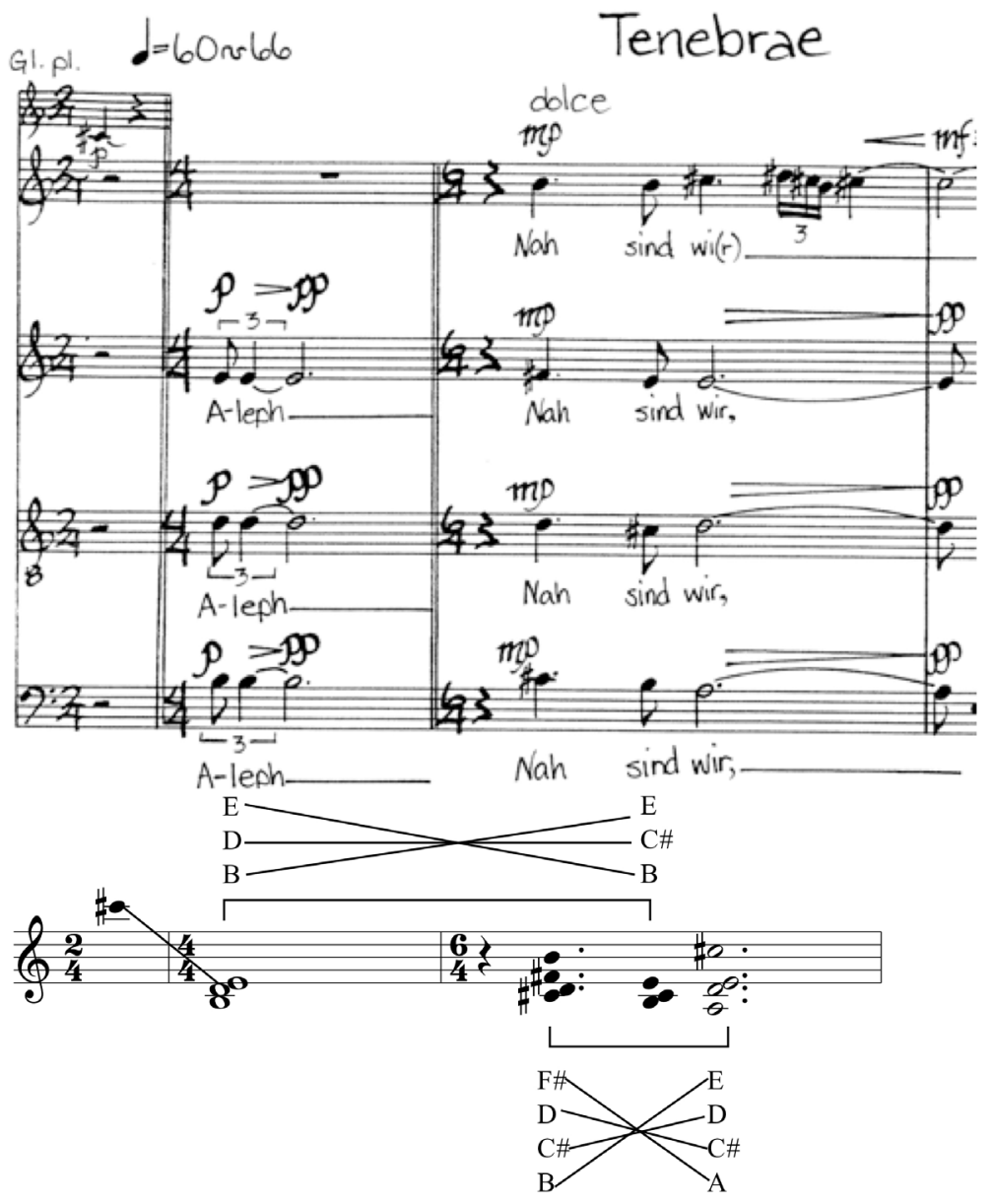

Figure 1. Tenebrae, mm. 1-3: Aleph and local harmony 

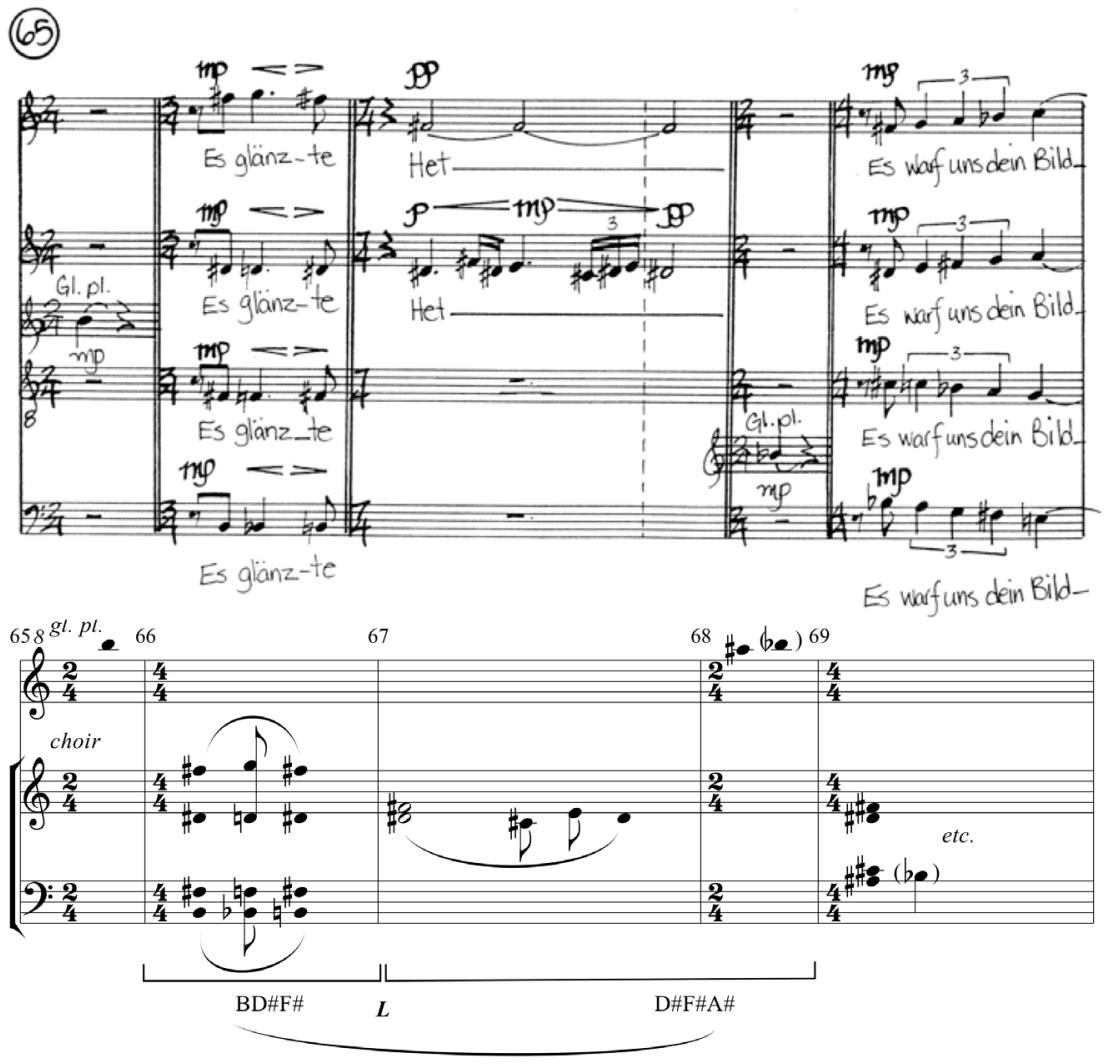

Figure 2. Tenebrae, mm. 65-9: Het and local harmony

supplying explicit biblical references, as well as excerpts by other authors relevant to the meaning of Celan's text, Cherney has at least suggested a path exegesis might take. ${ }^{14}$

For example, the texts following the first two Hebrew letters, including the first two sections of the poem, can be found on figure 3 , which provides a guide to the textual terrain of the first part of the composition.

The figure is laid out to show the different contributions of five different kinds of activity: the three indexing schemes-glockenspiel plates ("gl. pl.”), Hebrew letters ("acrostic"), and Herr (italicized within the poetic text); and

how Berio's work is framed by "Tenebrae" and a translation into German of a Hebrew poem by Dan Pagis, like Celan a native of Bukovina and a Holocaust survivor (Kerdiles 2015, 510). Further exploration of the subtleties of Osmond-Smith's argument will need to wait for another occasion.

14 The interpretive notes and textual resonances discussed by Felstiner $(1995,101-5)$ seem to have served as guides for Cherney here; they have also been essential to my own understanding of the poem. Among many other sources, I have found the poem's presentation in Bollack, Winkler, and Wörgerbauer (1991) to be particularly stimulating; Felstiner notes $(1995,306 \mathrm{n} 38)$ that at the roundtable following that presentation, Fred Lönker describes the Reitlinger reference we shall discuss shortly (146). 


\begin{tabular}{lll}
\hline GI. PI. & Acrostic & Tenebrae \\
\hline C\# & Aleph & \\
& & Nah sind wir, Herr \\
& & Nahe und greifbar
\end{tabular}

$\mathrm{C} \#$

\section{Beth}

Gegriffen schon, Herr

ineinander verkrallt, als wär

der Leib eines jeden von uns

dein Leib,

(Leib)

Herr.
Genealogy 1

Genealogy 2

(Hölderlin: Patmos)

Nah ist und Schwer zu fassen der Gott.

Wo aber gefahr ist, wächst

Das Rettende auf.

Im Finstern wohnen/Die Adler.

(Finstern)

(Reitlinger: Die Endlösung)

noch im Tode ineinander verkrallt

und verkrampft

Jetzt beginnt die wahre Hölle Now a real hell begins

\section{(Psalm 22)}

Be not far from me

for trouble is near

for there is none to help

(Reitlinger: The Final Solution)

clawing and mauling each other

even in death

Figure 3. Tenebrae: text layout for the setting of the first two sections of the poem 
two text-streams, "Tenebrae" itself and its textual genealogy. At the outset, this genealogy involves two additional texts; through most of the composition there is only one related text, and by the final section of the work this commentary vanishes, leaving the poem to stand naked in its final accusations. The first addition is also the first of two "cognate" poetic texts across the work, Friedrich Hölderlin's hymn "Patmos." Celan's opening couplet, "Nah sind wir, Herr; nah und greifbar," clearly reverses Hölderlin's more sympathetic address to a God who is near but not graspable; and even though the latter hymn passes through its own shadows, it suggests an optimism that clashes starkly with Celan's experience: "But where danger threatens / That which saves from it also grows," in Michael Hamburger's translation (Hölderlin 2004, 551). Against the last line of the Hölderlin, "In gloomy places dwell the eagles," Cherney overlays an excerpt from Psalm 22, another "call to witness": "Be not far from me." Alas, the eagles are indeed far; if the Hölderlin had continued, we could hear of a "chasm" over whose "bridges lightly built" "the sons of the Alps" could walk fearlessly, but that chasm is where those referred to in the Psalm have fallen. Their voices could not rise high enough. Poignantly, the poem dies away just as the Psalm reaches "for there is none to help."

Against "Tenebrae"'s second section, Cherney doubly juxtaposes a passage from Gerald Reitlinger's The Final Solution, in both its original English and in the German translation Celan read soon after it appeared in 1956 (Reitlinger 1953, 1956); we know that Celan took up a central poetic image from this book, the positions of agony in which the victims of the gas chambers were found (Felstiner 1995, 103). As figure 4 shows, both texts run simultaneously with the "Tenebrae" setting in one of the most complex sections of the composition, dense in texture and rhythm; the three closely related texts here form a kind of claustrophobic heterophony, well-suited to depict the terrors of a "clawing into each other."

The second poetic excerpt is a lengthy quotation from Dante. ${ }^{15}$ Cherney draws from canto 4 of the Inferno; the portion of the text he adopts is shown in figure 5, along with material he strategically omits. Here, in Limbo, those who lived before Christ, before baptism, spend their restless days. But many of the protagonists of the Hebrew Bible are expressly excluded: no Adam, Moses, Abraham, Rachel, etc., whose "shades" have all been rescued by Christ long before Dante arrives (Inferno, canto 4: 52-63). The presumably triumphant nature of their departure nevertheless leaves unsettling traces; there are graphic descriptions of the "suffering without physical torment" of those left behind, through their deprivation of the divine presence-yet the suffering of the Jewish people before they were "rescued" is unspoken. So Cherney enables the bearing of witness even here, in a domain that by definition exists in yet another linguistic register of tenebrae; even within this abyss, oscura e profonda

15 This connection is not suggested in the Felstiner commentary. In considering the interpretation of the Dante in this context, I have been greatly aided by the Digital Dante website at Columbia University, especially the commentary by Teodolinda Barolini, from which I depart slightly, given the contexts of Cherney's quotation (Barolini 2018). The site also contains the classic translation by Allen Mandelbaum. 


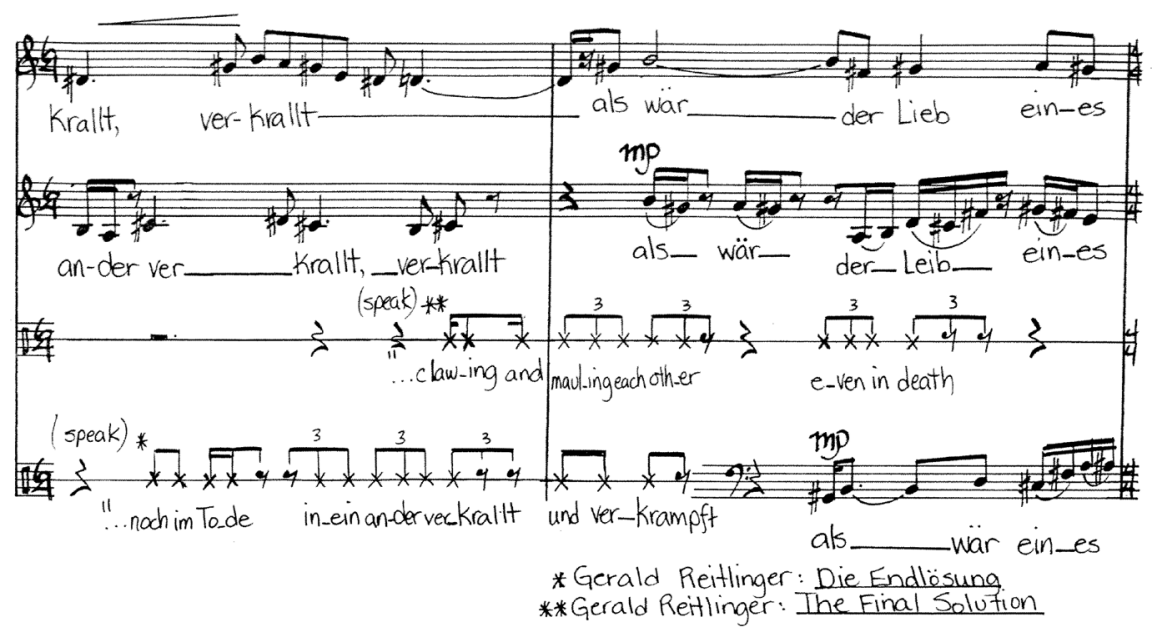

Figure 4. Tenebrae, mm. 23-4: layering of Celan with Reitlinger

7 Vero è che 'n su la proda mi trovai

In truth I found myself upon the brink

8 de la valle d'abisso dolorosa

of an abyss, the melancholy valley

10 Oscura e profonda era e nebulosa

That valley, dark and deep and filled with mist,

26 non avea pianto mai che di sospiri,

there was no outcry louder than the sighs

28 ciò avvenia di duol senza martiri,

The sighs arose from sorrow without torments,

29 ch'avean le turbe, ch'eran molte e grandi, out of the crowds-the many multitudes-

30 d'infanti e di femmine e di viri.

of infants and of women and of men.

38 non adorar debitamente a Dio:

they did not worship God in fitting ways;

Dante, The Divine Comedy, Inferno: Canto 4. Translation Allen Mandelbaum, available at https://digitaldante.columbia.edu/dante/divine-comedy/inferno/inferno-4/; crossed-out material omitted by Cherney 
era e nebulosa, we will not forget. Further, he casts doubt on Dante's typology of suffering. Cherney modifies canto 4: 28 to replace the chimera of "sorrow without torment" with simply "sorrow"; the Jewish people in the Inferno link up with those in the Shoah in the sense of divine abandonment, an abiding sense of existential anguish.

If Cherney's "hypertext" of "Tenebrae" were only a matter of exploring semantic connections, it would already be an achievement in enacting dialogue. But the text is also composed with an ear towards a variety of sound correspondences; the "hypertext" is itself a "poem," in the "post-Bloomian" sense championed by David Lewin: "The perception of a poetic work resides in the making of another poetic work" $(2006,103)$. The resonances that Cherney explores are not only semantic but also deeply sonic. Consider, on figure 6, the resonances that are brought out by the overlap of the Hölderlin and Psalm 22, in particular the way the initial consonant of "Finstern" in bar 15 is echoed by "far from me" on the following downbeat; and then the repetition of the same German word past the boundary of its initial text leads to an even tighter connection, spreading out its $f-r-s-n$ consonants into "for there is none."

It is here in the consideration of such sound correspondences that the reintroduction of the Hebrew letters has its most powerful effect. Those letters now interact with the text in a richly complex network-no longer an other, but a full participant in the conversation among languages. I hear this in operation from the beginning, as Aleph morphs into "Nah sind wir," preserving its initial "ah" vowel colour while voicing the final "ph" of the initial to $v$ in "wir"; this connection is enhanced by the harmonic links we have already discussed. By bars $27-8$, on figure 7 , the Hebrew letters are not even set off in every case; here, Gimel spills directly into the next bar, where its consonantal qualities $(g-m-l)$ are permuted to form the end of "wahnsinniger Eile" $(n-g$ - $l)$. And there too we can focus on how the relationships between translated texts are also set in

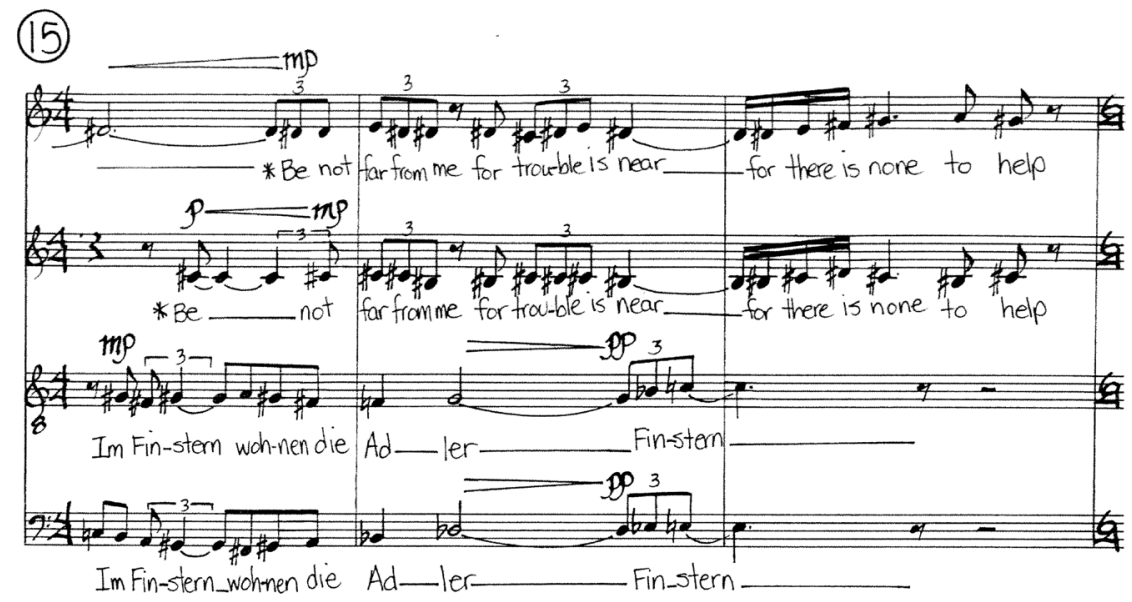

* Psalm 22

Figure 6. Tenebrae, overlap of "Patmos" and Psalm 22 


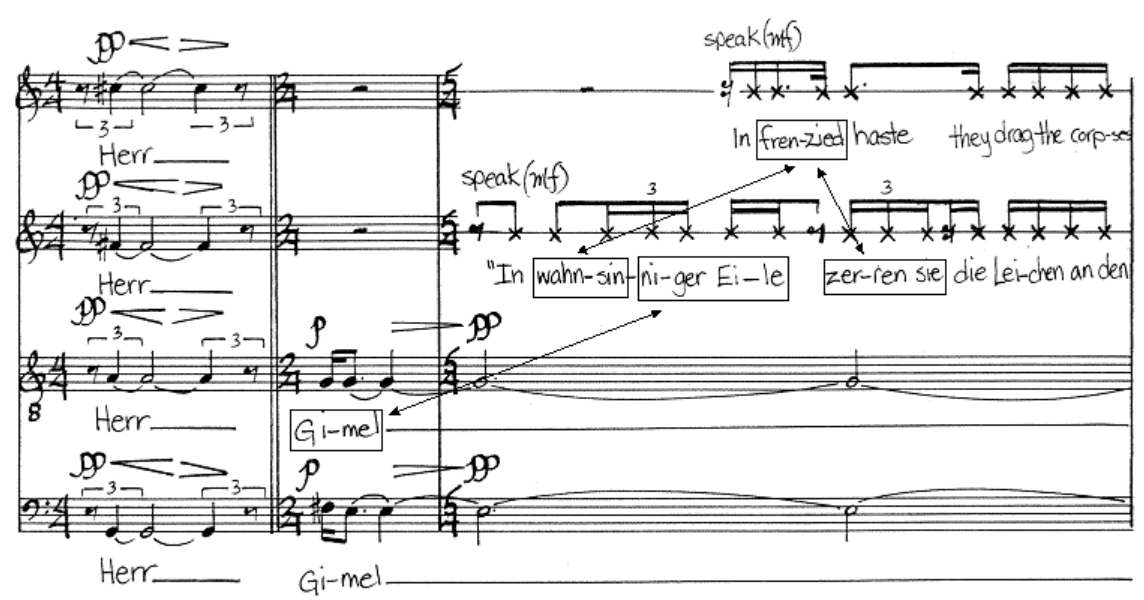

Figure 7. Sound correspondences in Tenebrae, 27-8

a way to permit similar correspondences to emerge: "in frenzied" pushes off from "wahnsinniger" and in turn makes an opening for "zerren sie" back in the German. Later, in bar 51, He appears as an incomplete form-or perhaps a precursor-of Herr, which follows two bars later; Vav in bar 54 introduces the second part of the Dante quotation, connecting to "avea" in the soprano in the following bar. ${ }^{16}$ There is much more to hear along these lines throughout the work.

But the connections are not forged merely by the juxtaposition of sounding words. A striking motion at the beginning of the Dante quotation, shown on figure 8, is a leap down and up a perfect fourth, the altos colouring the word Vero with the force of such an assertive interval. This shape occurs quite often within the Dante material, usually accompanied by some note that together with the fourth creates an [016] trichord. This is the case even here, with an A in the bass sounding together with the $G \sharp-D \sharp$, and then echoed as a cadence on trovai at the end of the bar.

What is "found" in "truth" is an abyss; when Cherney interrupts the Dante material with a brief return to the Celan text, the abyss is revealed to be the "water-trough" above which we "bend / over pit and crater." On figure 9, we find that the [016] motive is intensified with the setting of "Gingen wir"; this fast turn up and back along the fourth is one of the more jarring moments in the entire setting. And the [016] now infects the subsequent settings of Herr and Vav, and reaches its full flowering upon the return to the Italian, to the "sighs" louder than any "outcry"; some of the tight harmonic connections between trichords in this passage are shown below the figure, with common tones indicated in parentheses.

Many other such subtleties pose a musical argument for the hypertext, to partner with the linguistic and semantic structures it creates. Figure 10 reveals

16 As if to recapture the acrostic nature of the original text, Cherney allows the letter zayin to introduce the quotation from the prophet Zephaniah. 


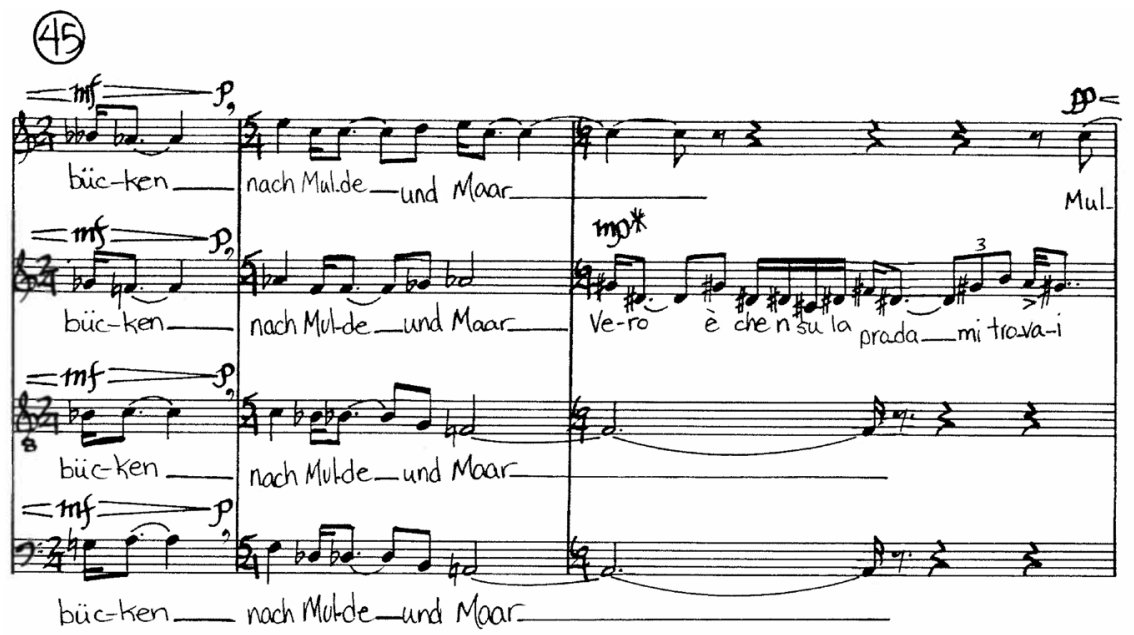

* Dante: Inferno, Canto IV

Figure 8. Tenebrae, mm. 45-7: introduction of Dante quotation

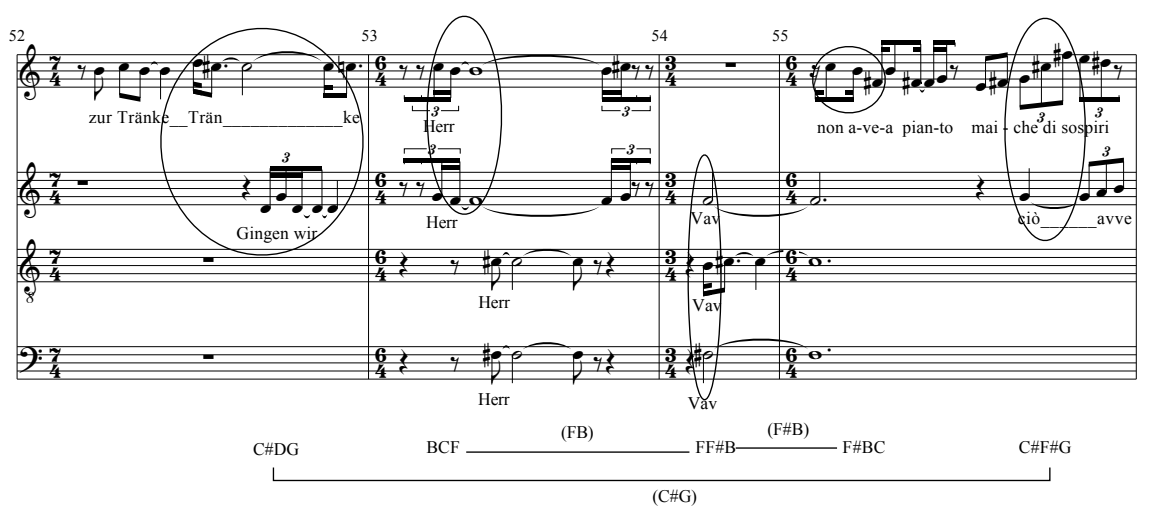

Figure 9. Tenebrae, mm. 52-6: Harmonic links between different text types

a different kind of musical connection. "Greifbar" on the downbeat of bar 8 marks a moment of considerable dissonance, articulating an [014] trichord that is all the starker for the attempts to avoid it made by the music just prior; it retraces the stark dissonance articulated by the first setting of Herr, which we shall turn to shortly. That is, this chord represents an impasse from which no resolution is forthcoming; as a result, the sopranos begin to sink in grief and find themselves tracing a chromatic path, from A down to $F \#$, that we shall refer to as the sigh motive. They pause on its last step, prolonging the $G$ at the end of bar 8, and then, after the glockenspiel plate has cleared, complete the fall onto $\mathrm{F} \#$. This is a reaching out to the second Hebrew letter, Beth-and also a reaching out beyond the poem, to the hypertext itself, which begins at this spot: not with reference to other words, but to other music: a quotation from 


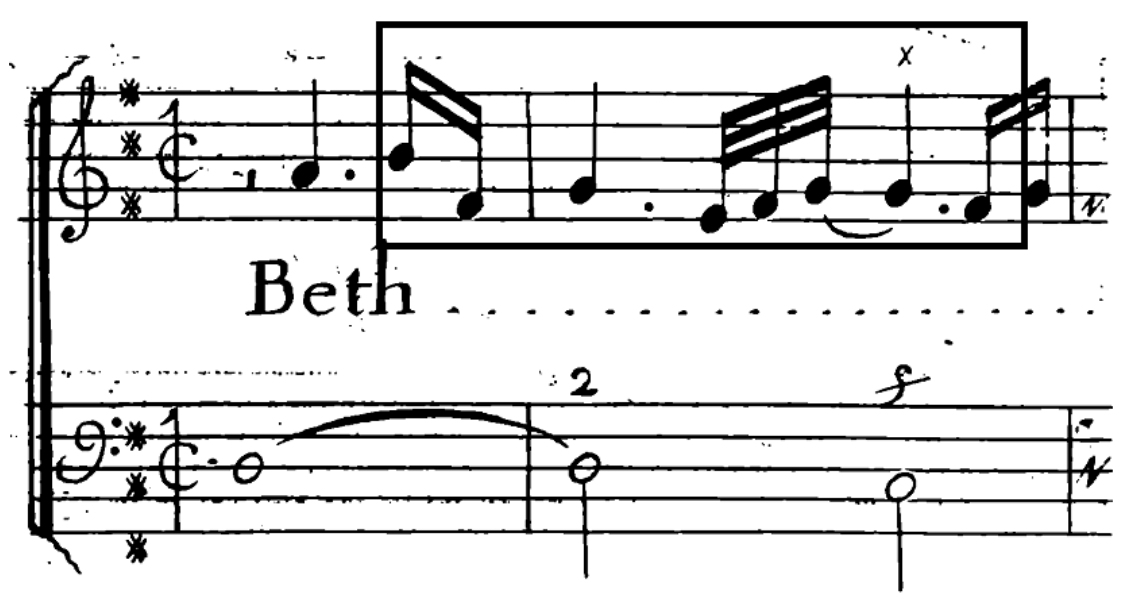

(10)

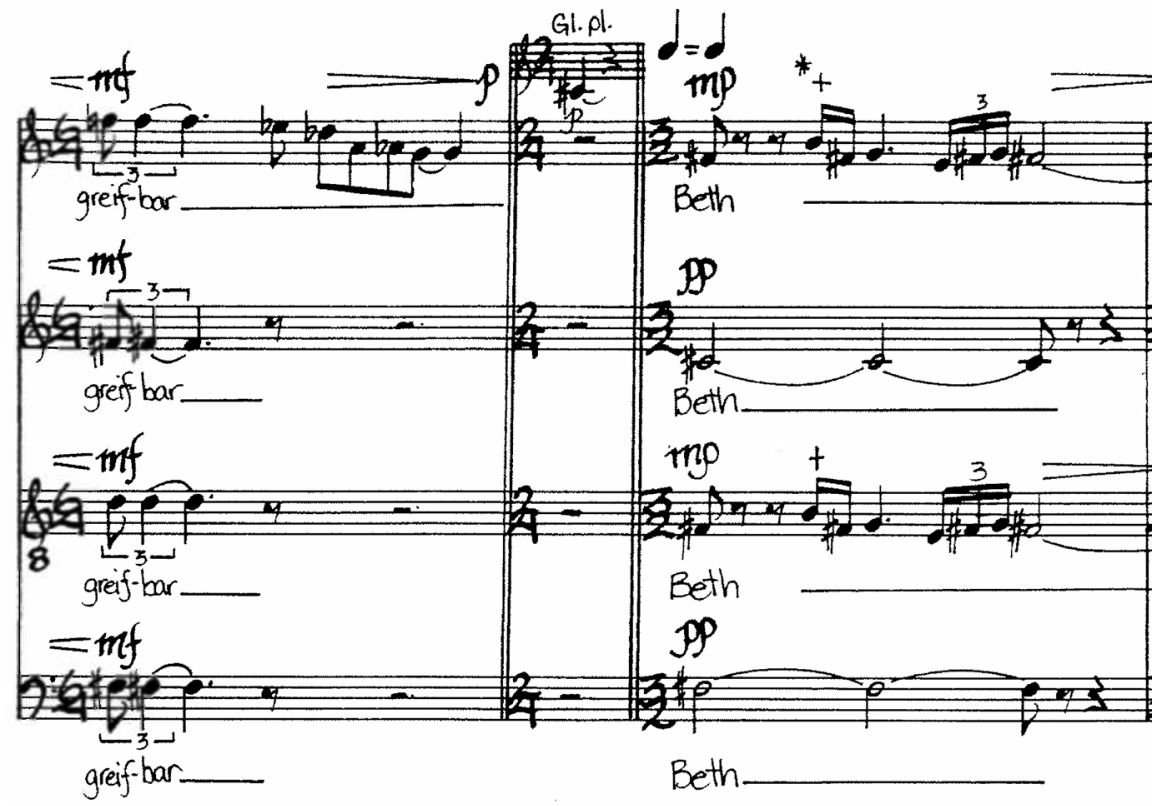

Figure 10. Quotation of Couperin setting of Beth

the Couperin Leçons, and specifically Couperin's setting of this same letter. ${ }^{17}$ The style of the Couperin itself has as little to do with Cherney's music as it does with Celan's poem; but for both, the earlier work is a springboard, a locus for reaction. Indeed, the musical reach of the Couperin fragment into the rest of the piece is considerable. By omitting the first note in the Couperin passage,

17 This is a less thoroughgoing reference to early music than that encountered in Cherney's Déploration, for harpsichord (spiteri 2000), but it generates significant musical material in Tenebrae. 
A, Cherney creates the first appearance of the motive of reaching up a fourth and back.

Even more important is the appearance of a turn, here surrounding $F \#$. It is not even the first time we have heard this gesture: the turn has already been introduced in bar 3, excerpted earlier on figure 1, marked there by the crossrelation it generated between soprano $\mathrm{D}_{5}$ and tenor $\mathrm{D}_{4}$. I interpret the clash as a warning: this is no mere ornament, but a certain way of establishing relatedness. In particular, it helps to clarify the sense of "near" relevant to an understanding of a poem so concerned with witnessing: we are near, Lord, because we are watching. The turn in the quotation lacks the same harmonic tension, but it solidifies its motivic importance. It recurs throughout, most beautifully at two cadential points in the setting: at bar 36, when the initial "Nah sind wir" is inverted to "wir sind nah," and when this "inverted" text appears again at the very end of the composition. In both versions the direction of the turn is also reversed, the quality one of lament, reminiscent indeed as its lower section is elaborated of a kind of cantillation. And this reminder casts the critique of the role of Hebrew letters in Lamentations settings in a new light. Perhaps in some cases the kind of florid cantillation that characterizes many decorative settings of the Hebrew letters is at least in part a way in which a specifically Semitic kind of melody - or at least the image of such a melody, through whatever source-was reinscribed in these pieces. Perhaps, that is, such settings were at least in some cases not attempts to create mere decorated capitals, but actually sincere and creative reactions to the absence signified by these letters. ${ }^{18}$ It seems to me that Cherney could be understood here as engaging this interpretation, imbuing the fabric of this intertextual composition with such echoes. ${ }^{19}$

It is not the case-it could not be the case-that sympathy remains the primary mode for the interaction of all the textual elements; and here a consideration of other musical details of the setting will be crucial. In particular, while the Hebrew letters in Cherney's setting exist in a symbiotic-almost, indeed, a consubstantial-relationship with Celan's text, Herr often stands apart. After the first couplet comes the first setting of Herr, shown on figure 11; this is the most dissonant event in the piece so far, voiced to emphasize the compound minor ninth between the outer voices. The altos seem to want to crawl away from this, to somehow make the chord less horrible. However, they only succeed in intensifying the clash, articulating a chromatic descent that we have already referenced as the sigh; at its end, F\# is doubled, reinforced against the bass F.

This kind of internal life in the setting of the word is a powerful feature of Cherney's setting. Birtwistle, for instance, has his soprano sing "Lord" on an extended and sharply articulated E5 all eleven times it occurs; this acts as a

18 I am certain this idea is not original with me, but alas I cannot now trace the source from which I gleaned it.

19 In his prefatory note, the composer writes, "I have set Celan's poem in a fairly straightforward, syllabic style, contrasting with the more linear approach in the added fragments." The turn figures are such effective markers in the setting precisely because of their slight deviation from this sober approach to Celan's text. 


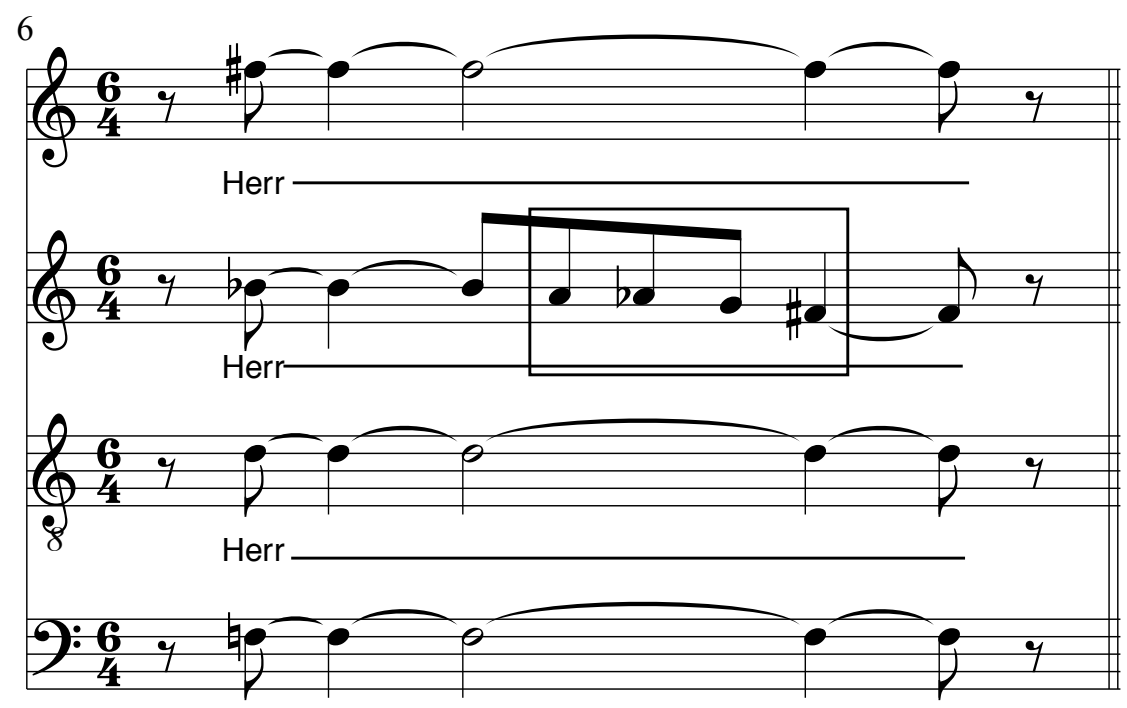

Herr-

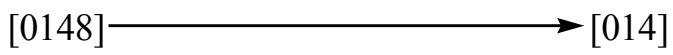

Figure 11. Tenebrae, m. 6: first setting of Herr and first appearance of sigh

trigger for instrumental activity, characteristically a scampering clarinet fanfare starting with chromatic neighbours to that $\mathrm{E}_{5}$. But the note itself remains stubbornly unresponsive, a tandem that creates a nearly unbearable tension as its appearance accelerates across the poem. Berio, by contrast, places "Herr" on his baritone's lowest note, A2, generally situating the material preceding "Herr" in its highest register in order to emphasize the separation across the singer's entire range. Osmond-Smith notes that this placement below rather than above is well in keeping with the "inversion" of Celan's text (Osmond-Smith 2004, 66); indeed, the only exception occurs at the end of the line "The blood, and the image that was in the blood, Lord," where the reflection of the Lord's image is set towards the other end of the range, on $\mathrm{B}_{3}$. There is no consistent reflection of the note in the accompaniment, as there is in Birtwistle's setting; Berio tends to double the A2 in a variety of ways, using the wide orchestral palette at his disposal.

Perhaps Wolfgang Rihm's setting of Tenebrae for chorus and orchestra, as the last movement of his Deus Passus, provides the closest point of comparison with Cherney here. Initially Rihm sets "Herr" on a first inversion A-minor triad, using a five-voice subset of his chorus. The disjunction of the soloists with the full chorus well manifests the unreachable deity, who stubbornly clings to this triad despite the varied entreaties of the larger complement of singers. The Lord gives way once, moving from the triad to a closely voiced C-minor ninth; in a striking parallel to Cherney's first setting of the word, this 
is voiced with the minor ninth in the outer parts. Soon after, Herr is taken up by the full chorus; and the setting of "It was blood, it was / what you shed, Lord," "Lord" in the chorus intrudes very early, and the A-minor triad is dramatically forsaken, collapsing onto a column of the minor second $\mathrm{B}$ and $\mathrm{C}$ in two octaves. The A-minor triad does not recur. From this point on, until the penultimate stanza with its fourfold Herr, Rihm sets the word differently every time it occurs; at that stanza, the first three occurrences are identical, with the final setting on an octave $\mathrm{B}$, the soloists returning to the word in unison with the rest of the chorus.

Still, though, this considerable variety does not quite match what Cherney accomplishes here. In his Tenebrae, every setting of Herr is unique; even when the same basic chord type appears in more than one setting, its motivic shape is differentiated. The inconstancy of the Lord stands fully revealed. A rough sense of this variety can be gathered from figure 12, which indicates the tetrachordal content of each setting, along with three special shapes: sigh, cross, and waver. ${ }^{20}$ On the figure, I have included the setting of Dio that concludes the Dante quotation; this is treated exactly like other Herr settings, another way Cherney draws strong connections across his different kinds of textual material. ${ }^{21}$

We have already encountered the sigh, a falling chromatic tetrachord. The second time it occurs, on the penultimate setting of Herr, in bar 79, it undermines rather than intensifies the chord that initiates it; the result achieves

\begin{tabular}{lll}
\hline Herr & bar & PCset/motive \\
\hline 1. & 6 & {$[0148]+$ sigh $([014])$} \\
2. & 20 & {$[0236]$} \\
3. & 26 & {$[0137]$} \\
4. & 32 & {$[0347]+$ waver } \\
5. & 53 & {$[0168]+$ cross $([012678])$} \\
(Dio & 58 & $[0148]+$ waver $)$ \\
6. & 62 & {$[0347]+$ cross $([01469])$} \\
7. & 71 & {$[0347]$} \\
8. & 74 & {$[0167]$} \\
9. & 75 & {$[0158]$} \\
10. & 79 & {$[0358]+$ sigh $([0247])$} \\
11. & 82 & {$[0237]+$ waver } \\
\hline
\end{tabular}

NB: cross motives give entire pc content of figure; sigh and waver only include first chord; if the final chord changes, that is given in parentheses (\#1 and \#10)

Figure 12. Varieties of Herr settings

20 This sense of waver, incidentally, seems to be obsolete; but a beautiful "model sentence" from the mid-sixteenth century could not better capture the sentiment here: "I stande in doubte or in a waver." "waver, n.3." OED Online. http://www.oed.com/view/Entry/22640o?rskey=ie79H9\&result=3.

${ }^{21}$ It is worth noting that this privilege is not accorded by Cherney to Hölderlin's Gott; this is still the God whom we must grasp, rather than the Lord who must grasp us. 


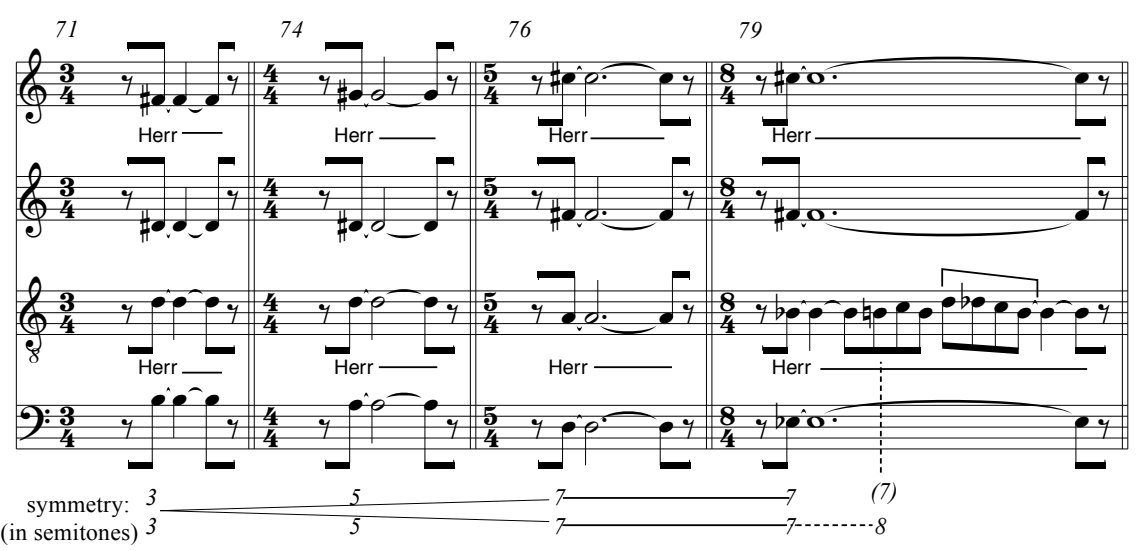

Figure 13. Symmetry of Herr settings, mm. 71-9, disrupted by final sigh

something of the effect that Berio's registral reversal mentioned earlier musters at the same point in his setting, with quite different means. The fourfold settings of Herr in the penultimate stanza are excerpted on figure 13. Cherney's previous settings of Herr in this stanza have not only been symmetrical tetrachords, but in fact have been voiced as symmetrical juxtapositions of increasingly larger intervals.

On the figure, the absolute sizes of the intervals are shown beneath. So in the setting of Herr in bar 71 , three semitones ( $\mathrm{B}_{3}$ to $\mathrm{D}_{4}$ ) are paired with three semitones ( $\mathrm{D} \sharp 4$ to $\left.F_{4} 4\right)$; in the setting in bar 74 , five semitones ( $A_{3}$ to $D_{4}$ ) are paired with five semitones ( $\mathrm{D} \sharp 4$ to $G \sharp 4)$, and so forth. The last setting too begins symmetrically, but it fails to follow the pattern of growth that has moved thus far from minor thirds to perfect fourths to perfect fifths. It seems to have become stuck; it merely replicates the perfect fifth, rather than increase two semitones to the major sixth as the pattern suggests. The sigh at least disturbs the perfect fifth-based symmetry, although it ends a semitone short of achieving the pattern. But there is no corresponding move above it, so symmetry is completely undermined-at just the point where the text has suggested a physical symmetry, a reflection (Bild) in the blood that we have drunk. Thus the reflection is rendered imperfect, musically; the image of the Lord cast into our eyes is distorted. There is a comparable broken strategy concerning duration: a gradual growth in length across the first three Herr settings on the figure is disrupted by the distended length of the last, an expansion due to the appearance of the sigh.

The cross shapes, on figure 14, also involve broken symmetry. Of course, a reference to such imagery is tendentious in this context for many reasons, not the least of which here is the unsuccessful attempt made by a number of critics to read Tenebrae as invoking a Christian theology of reconciliation (Felstiner 1995, 104-5); still, the two events to which I have assigned this description 


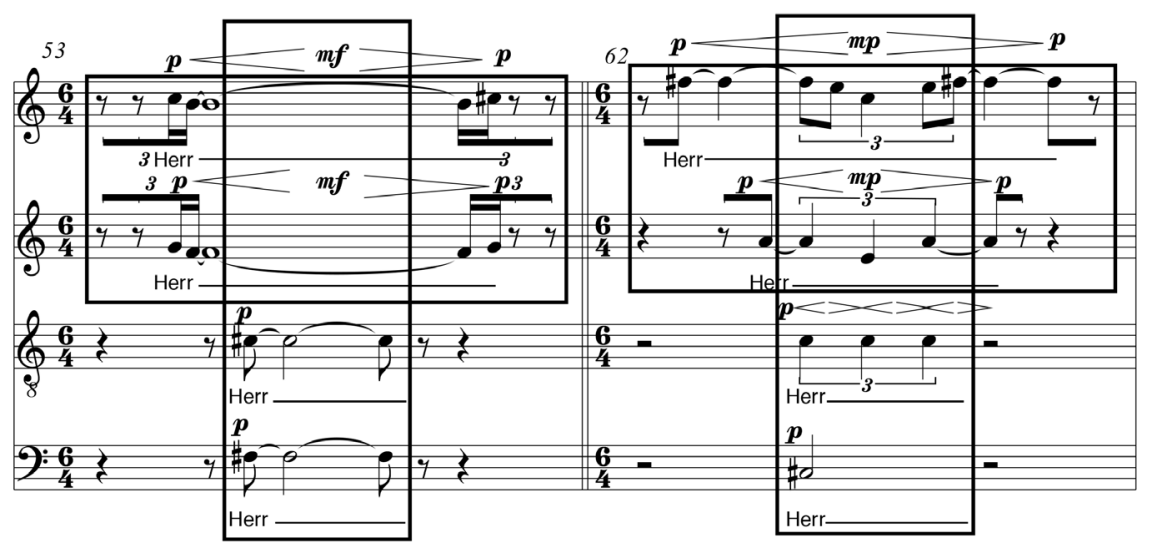

Figure 14. Instances of the cross motive

remind me strongly of the deliberate adoption of the cross as a score layout by Luigi Dallapiccola in his Cinque Canti (Alegant 2010, 56-7). ${ }^{22}$

The first cross is skewed only by the soprano's final note, $\mathrm{C} \# 5$ rather than the C5 with which it started; the second cross is displaced rhythmically by the bass, which does not align with the central "column." 23 The hairpin dynamics support the shape's symmetry, lending in both settings the sense of a Lord caught up in his own affairs; this is intensified in the second cross, with its threefold swells on $\mathrm{C}_{4}$, especially as the texts on either side, from "Tenebrae" and its echo in Zephaniah, are concerned with the pouring out of blood. ${ }^{24}$

Not only does the waver have a consistent shape, but in fact it occurs exactly the same way all three times, albeit in subtly changing contexts: as can be traced on figure 15 , the tenor starts out on $\mathrm{B}_{3}$, dips to $\mathrm{A}_{3} \mathrm{~b}_{3}$ by way of $\mathrm{B}_{3}{ }_{3}$, and returns. I read this as a particularly powerful evocation of a Lord whose certainty is lost, who knows not which way to turn, perhaps overwhelmed by tragedies of such scale. ${ }^{25}$ Given the different originating harmonies, each time the waver entertains a different relationship to the whole; what links all three is the sense of opportunities not taken, failed reconciliations, and ultimately resignation. On the first waver, the tenor temporarily moves the chord into

22 Dallapiccola's cross figure nicely adorns the cover of his book. It seems striking that Cherney's two cross settings occur roughly in the middle of the list on figure 12, as if their property of near-symmetry is carried out in the larger composition.

23 The rhythmic symmetry invoked here is one of duration rather than attack point; so the shape will inevitably have an Augenmusik flavour, as much as Cherney realizes the design in a way that suggests a symmetrical core.

24 Indeed, the descent into the middle of the second cross is evocative of pouring.

25 I am grateful to an anonymous referee for suggesting instead that these wavers could be understood as instances of the circulus, or circulatio figure, famously employed by numerous masters of text painting such as Josquin and Lassus; Warren Kirkendale presents examples of the figure as far as Beethoven (1984). Most often, it depicts some notion of the perfect, possibly also the idea of celestial circles-even infernal ones (Kirkendale cites the Dantean use of the figure in the Mozart Confutatis). But Cherney's figure instead seems to emphasize the undermining of divine perfection; Celan's deity turns back, defeated. This is a gesture of indecision and, ultimately, failure, not one of triumph. 


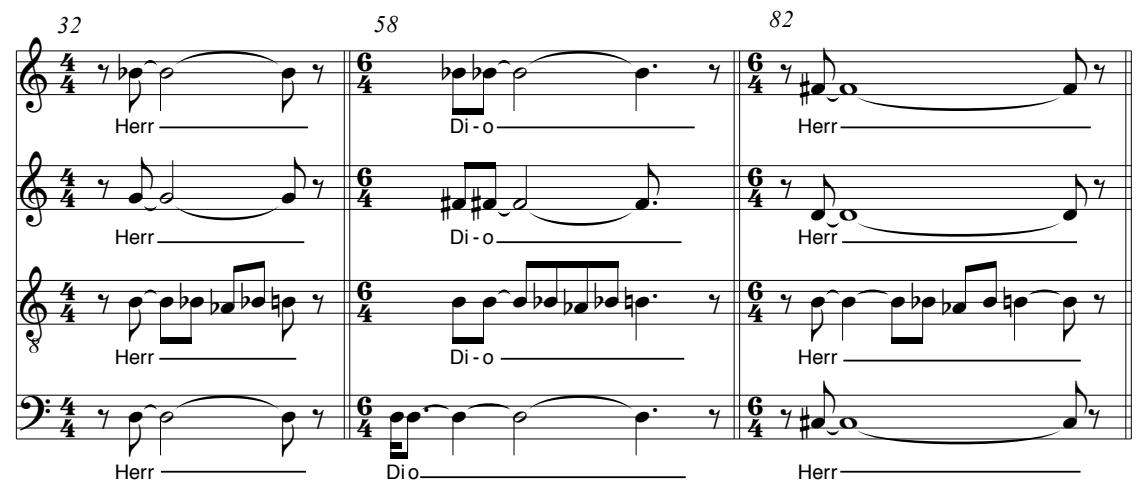

Figure 15. Instances of the waver motive

a "pure" G-minor sonority before moving back out to its ambivalent major/ minor origin. Something similar happens in the setting that accompanies Dio, although here the $\mathrm{B}^{b}$ would solidify an augmented triad, possibly a site of even more ambiguity than the [0148] back to which it eventually settles, with its mere glimmer of a B-minor triad. The last time the chord starts in fact with a B-minor triad, but the root is placed in the unsteady tenor, with an added major ninth inverted below. When the B departs along the waver, it is as if the note is rejecting its status; it will not serve as foundation, seeking to displace this onto another.

Kerdiles, in his survey of settings of "Tenebrae," remarks on the traditional forces employed, scored for solo voice and ensemble or a cappella chorus. ${ }^{26}$ He asks rhetorically if this is due to the form of the text, with its traditional trappings; or if rather this can be attributed to an attitude of modesty in response to the horrors of the text itself $(2015,511)$. Whether this is an entirely fair assessment of the reactions of the other composers must be deferred here; but Cherney enhances the structure of the text to confront its meanings headon. His approach reimagines Celan's poem in ways that are deeply immersed in Celan's own symbolic and textual world view. This is, of course, to take on considerable risks, whether the forces employed are conventional or not. Rihm's setting of "Tenebrae" again appears to be a useful point of comparison; there, Rihm places the work at the conclusion of a highly idiosyncratic treatment of the Passion according to St. Luke. ${ }^{27}$ Critics such as Seth Brodsky and Arnold Whittall have explored how Rihm's setting renders deeply problematic

26 In addition to the Birtwistle and Berio settings discussed earlier, Kerdiles also engages with an early a cappella setting by Nicolaus Huber. It is not entirely clear why he chose only these three; he mentions the Deus Passus setting in passing, but claims incorrectly that Rihm used only fragments of the text (Kerdiles 2015, 499).

27 Johann Jakob Van Niekerk has pointed out a different way in which "Tenebrae" featured in the composer's conception of the work: "In interviews regarding Deus Passus, Rihm mentions the journey of the German language through 'thousand darknesses.' Van Niekerk links this to Celan's 'Bremen' speech, delivered in 1958, the year after Tenebrae was written: 'It, the language, remained, not lost, yes in spite of everything. But it had to pass through ... the thousand darknesses [die tausend Finsternisse] of deathbringing speech"” (Van Niekerk 2014, 77; Celan 2001, 395). 
any Passion narrative after the experiences of the Holocaust; Whittall speculates that "this text threatens to render the preceding Gospel text irrelevant, and that could be the whole point" (Brodsky n.d.; Whittall 2003, 144). Linking Celan to a Passion narrative, even in an ironic vein, is unsettling; we know that in the final year of his life he rejected a chance to hear the St. Matthew Passion of Bach, although his reasons are unknown (Felstiner 1995, 282; Marteau 2015, 49). But more fundamentally, I worry that this use of the poem intervenes decisively in a dispute within the Christian world in which Celan is a bystander, rather than responds to the need for reflective witness that Celan and Cherney have called us to. ${ }^{28}$ In Celan and Cherney, at the end of poem and composition, there is no resolution; there is instead resignation, and sadness, and at least in the setting a hope: that through the authentic experience of connection, in words and in music, what happened will not happen again.

\section{REFERENCES}

Alegant, Brian. 2010. The Twelve-Tone Music of Luigi Dallapiccola. Rochester: University of Rochester Press.

Barolini, Teodolinda. 2018. "Inferno 4: The Cultural Other." In Commentaro Baroliniano, Digital Dante. New York: Columbia University Libraries. https://digitaldante.columbia.edu/dante/divine-comedy/inferno/inferno-4.

Bollack, Jean, with Jean-Marie Winkler and Werner Wögerbauer. 1991. Tenebrae. In "Sur quatre poèmes de Paul Celan: une lecture à plusieurs." Revue des sciences humaines 223:121-70.

Bonnet, Antoine, and Frédéric Marteau, eds. 2015. Paul Celan, la poésie, la musique: Avec une clé changeante. Paris: Hermann.

Brodsky, Seth. n.d. "Description." https://www.allmusic.com/composition/ deus-passus-st-luke-passion-oratorio-for-soloists-chorus-orchestramcooo2556398.

Celan, Paul. 2001. Selected Poems and Prose of Paul Celan, trans. John Felstiner. New York: W.W. Norton.

David, Hans T. 1972. "Hebrew Letters in Polyphonic Settings by Christian Composers." Bach 2 (2): 6-17.

Englund, Axel. 2012. Still Songs: Music in and around the Poetry of Paul Celan. Farnham, Surrey: Ashgate.

Felstiner, John. 1995. Paul Celan: Poet, Survivor, Jew. New Haven, CT: Yale University Press.

- 2010. "Apostate Only I am True': Paul Celan's Poetry and His Devotion." Religion and Literature 42 (3): 198-205.

28 And by engaging with this here, I realize I too will have seemed to enter the dispute; but I mean only to draw attention to this uneasiness, which I see no obvious way to resolve. And there are further musical grounds to explore it; the initial setting of "Herr" in the Rihm-a first inversion A-minor triad as I mentioned earlier -is also exactly the choral voicing at the outset of Arvo Pärt's Passio, a setting of a passion text (after the Gospel according to John) whose anti-Semitism has occasioned much controversy. If I am right to hear this as a direct reference, it intensifies the sense of a reference loop within the world of Christian reaction, as opposed to an expanded dialogue in which the Celan could be accorded a place. 
Hölderlin, Friedrich. 2004. Poems and Fragments, trans. Michael Hamburger. London: Anvil.

Janz, Marlies. 1976. Von Engagement absoluter Poesie: Zur Lyrik und Ästhetik Paul Celans. Königstein: Athenäum.

Joyce, Paul M., and Diana Lipton. 2013. Lamentations through the Centuries. Chichester, West Sussex: John Wiley \& Sons.

Kerdiles, Dmitri. 2015. "Sur trois lectures musicales de Tenebrae: Huber, Birtwistle, Berio." In Bonnet and Marteau 2015, 499-512.

Kirkendale, Warren. 1984. "'Circulatio'-Tradition, 'Maria Lactans,' and Josquin as Musical Orator." Acta Musicologica 56 Fasc. 1, 69-92.

Lewin, David. 2006. "Music Theory, Phenomenology, and Modes of Perception." In Studies in Music with Text, 53-108. New York: Oxford University Press.

Marteau, Frédéric. 2015. "Portrait du poète en mélomane. Une esquisse biographique." In Bonnet and Marteau 2015, 15-68.

Osmond-Smith, David. 2005. "Als geübteste Ferne': Birtwistle incontra Celan." In Paul Celan-Harrison Birtwistle: I silenzi della poesia e le voci della musica, ed. Luigi Forte, 57-77. Alessandria: Edizioni dell'Orso.

Parry, Robin. 2011. "Wrestling with Lamentations in Christian Worship." In Great Is Thy Faithfulness? Reading Lamentations as Sacred Scripture, edited by Robin A. Parry and Heath A. Thomas, 175-97. Eugene, OR: Pickwick Publications.

Pöggeler, Otto. 1986. Spur des Worts: zur Lyrik Paul Celans. Freiburg: K. Alber. _ 1993. "Die göttliche Tragödie: Mozart in Celans Spätwerk." In "Der glühende Leertext": Annäherungen an Paul Celans Dichtung, edited by Christoph Jamme and Otto Pöggeler, 67-85. Munich: Wilhelm Fink Verlag. Reitlinger, Gerald. 1953. The Final Solution: The Attempt to Exterminate the Jews of Europe, 1939-1945. London: Vallentine, Mitchell.

—_. 1956. Die Endlösung: Hitlers Versuch der Ausrottung der Juden Europas, 1939-1945, trans, J.W. Brügel. Berlin: Colloquium Verlag.

Ricketts, Matthew. 2017. "Texts-Textures-Intertexts: The Orchestral Worlds of Brian Cherney." DMA diss., Columbia University.

spiteri, vivienne. 2000. "Déploration-In Memoriam Morton Feldman by Brian Cherney, and in Conversation." Contemporary Music Review 19 (4): 73-103.

Van Niekerk, Johann Jacob. 2014. "Messiahs and Pariahs: Conscience in the Passion Genre from J.S. Bach's St Matthew Passion (1727) to David Lang's the little match girl passion (2007)." DMA diss., University of Washington. Vincent, Jean Marcel. 2007. "La figure de l'inversion dans le poème Tenebrae de Paul Celan." Revue de théologie et de philosophie 57 (3): 205-25.

Whittall, Arnold. 2003. Exploring Twentieth-Century Music: Tradition and Innovation. Cambridge: Cambridge University Press.

\section{ABSTRACT}

In several compositions, Brian Cherney has reflected on the Holocaust and its impact, exploring how music can respond to such tragedy; his recent engagement with 
the poetry of Paul Celan is a natural extension of these preoccupations. This article offers a close reading of Cherney's choral setting of Celan's Tenebrae. The composer incorporates several additional texts that create a genealogy of the poem, from biblical passages to fragments of Dante and Hölderlin to accounts of the Holocaust itself; he arranges these texts to highlight semantic and sonic features of Celan's work. Perhaps Cherney's boldest move is his insertion of Hebrew letters, linking his composition to the long tradition of Lamentations settings-a link cemented by a quotation from Couperin's Leçons de Ténèbres, which provides important motivic material. Through these additions, Cherney turns the poem towards us, inviting us to respond to its call for reflective witness.

\section{RÉSUMÉ}

Plusieurs compositions de Brian Cherney sont une réflexion sur l'Holocauste et son impact; elles explorent la manière dont la musique peut répondre à une telle tragédie. Son rapprochement récent de la poésie de Paul Celan constitue un prolongement naturel de ces préoccupations. Dans cet essai, l'auteur propose une lecture intime de l'interprétation chorale par Cherney du Tenebrae de Celan. Le compositeur intègre plusieurs textes additionnels qui créent une généalogie du poème, notamment des passages bibliques, des fragments de Dante et Höderlin, et des comptes rendus de l'Holocauste comme tel; il structure ces textes pour mettre en valeur les aspects sémantiques et soniques de l'œuvre de Celan. La décision sans doute la plus audacieuse de Cherney a été d'inclure des lettres hébraïques, faisant ainsi le lien entre sa composition et la longue tradition du cadre des Lamentations; ce lien est renforcé par une citation des Leçons de Ténèbres de Couperin, créant un matériel motivique important. Par ces ajouts, Cherney nous renvoie le poème et nous invite à répondre à son appel à être des témoins réfléchis.

\section{BIOGRAPHY}

Anton Vishio is an assistant professor of music at William Paterson University, where he teaches music theory and composition. His work has focused on the analysis of late twentieth-century music, as well as text-music relationships. In addition to forthcoming articles on music by Priaulx Rainier and Charles Wuorinen, he is preparing essays on Luigi Nono and on musical settings of Rabindranath Tagore. 